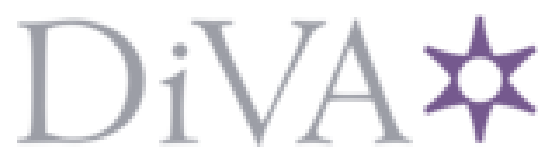

http://www.diva-portal.org

\title{
Postprint
}

This is the accepted version of a paper published in Childhood. This paper has been peer-reviewed but does not include the final publisher proof-corrections or journal pagination.

Citation for the original published paper (version of record):

Lindgren, A., Sparrman, A., Samuelsson, T., Cardell, D. (2015)

Enacting (real) fiction: Materializing childhoods in a theme park.

Childhood, 22(2): 171-186

http://dx.doi.org/10.1177/0907568214524460

Access to the published version may require subscription.

N.B. When citing this work, cite the original published paper.

Permanent link to this version:

http://urn.kb.se/resolve?urn=urn:nbn:se:hj:diva-23680 


\section{Enacting (real) fiction: Materializing childhoods in a theme park}

Anne-Li Lindgren, Anna Sparrman, Tobias Samuelsson and David Cardell

Fiction and fantasy are highly valued in children's worlds. The capacity to move in and out of pretend play and to explore and understand fictive fantasy worlds is described as natural, normal and even desired in psychological, pedagogical and sociocultural, or anthropological theories about play (Cannella and Viruru, 2004; Lindgren, 2006). Yet, when it comes to children's computer gaming based on fictive fantasy worlds (Aarsand, 2007), pretending to be a pop star (Sparrman, 2002), or watching television (Pettersson, 2013), moral panics about whether children can see and comprehend differences between the real and the fictive arise. In addition, children's theatre can be blamed for luring children into fictive fantasy worlds where the lack of understanding about what is real and unreal is upheld as problematic (Helander, 2011). Even though fiction and fantasy are fundamental to how childhoods today are understood, this is a topic that is seldom explored either theoretically or academically. We want to address the question of how the relationship between real and unreal can be understood in new ways in contemporary society. We suggest that fiction can be understood in other ways than the hitherto dichotomized approaches to it, and our aim is to focus on the hybridity that is created through the interconnecting word and; as in fiction and childhood, material real and fictive real. We are particularly interested in how materiality as something real and fiction as real mingle, and thus we chose to talk about what we call the fictive real and realunreality.

In order to study fiction as a hybrid and interrelated phenomenon we have chosen a theme park created around the works of the prestigious Swedish author Astrid Lindgren; i.e. Astrid 
Lindgren's World (ALW). ALW is just one manifestation of Lindgren's works that have proliferated on an everyday basis in novels, films, plays, games, broadcasts and on the Internet. The theme park ALW is situated on the outskirts of Lindgren's birthplace, the small Swedish town of Vimmerby, and it provides opportunities to walk through and explore the fictive fantasy worlds of Lindgren's famous novels in an imaginary and material model world (Sparrman, 2011). The target group for the park is 'children 0-9 years with their families' (www.alv.se, retrieved 24 September 2012), signalling that this is a place that primarily addresses children and only secondarily adults. By taking this approach, the park attracts 450,000 visitors per year - mainly in the summer months - and prompts millions of people to document and share their experiences on the Internet (Danielsson et al., 2011). The built scenarios, or 'events', in the park are inspired mainly by the illustrations in the Swedish editions of the books, and to some extent by the settings from screen adaptations (Althén, 2010). There are also outdoor theatres continuously staging plays inspired by Lindgren's novels. Actors impersonate the fictional characters from Lindgren's novels, performing on one of the two stages or mingling with the visitors. In all the events, the actors - separately and together with visitors - enact fiction in different ways in the park. An important ingredient in this enactment of fiction is, we argue, the interaction between the embodiments of Lindgren's fictive childhoods and the real childhoods brought into play by the visitors (by children and adults).

Previous theme park research has pointed out that the incorporation of fiction serves to stimulate the visitor's imagination, a strategy designed to give the 'feeling of being transported to another place or time' (Lukas, 2008: 12-13), or being in a 'toy city' (Eco, 1998: 41). Another more common interpretation is that theme parks are about managing emotions in order to make the visitors consume (Cardell, 2013). In this paper we go beyond these interpretations with focus on how the visitor is lured by the theme park management. We 
interpret 'the hallucinatory' effect that Umberto Eco (1998) refers to, not as a threat to realism or reality, but rather as part of contemporary childhoods, which are interconnecting with the fictive; a kind of fictionalization of childhood practices creating realunreality. Our focus is on how the material real and the fictive real mingle with childhoods in actual practices and what that might mean.

In order to explore the position of fiction in the park, we discuss it as an enacted practice. By this we mean that fiction, in addition to being constructed in practice, helps to make what fiction 'is' through this practice (Law, 2004; Law and Urry, 2003). This means that fiction at ALW enacts and re-enacts specific and complex realities in which, for example, the fictive and childhood create each other, but also that the fictive and childhood are mingled and created in relation to materiality, semiotics and live actions. Through this approach, entanglements of fiction and childhood remap the boundaries between the material real and fictive real enacting 'a contested gradient of realness' (Law, 2004: 4), where the fictive stimulates real activity (Woolgar, 2002: 17) and, we add, vice versa. We explore this by posing two interrelated questions that will guide the analysis: What does the material real and fictive real assemblage of the theme park do? What kinds of enacted childhoods does the materialized fiction in the park enable?

The analysis is based on the places that the park itself refers to on maps and in the park guides as 'events'. The material was collected as part of a research project aiming to make a visual documentation of the theme park (VR 2009-2384), since such places are not included in the documentation activities conducted by, for example, Swedish museums to preserve places, buildings and areas which are or might become parts of cultural heritage (ALW defines itself as a place of cultural heritage; Sparrman, 2011). Four researchers conducted the visual documentation; photographing and writing down key aspects of the constructed park events. The analyses of the place based on this visual documentation are supplemented with another 
kind of visual material: films uploaded onto YouTube by parents after having visited the park. YouTube offers a number of films from ALW park visits. We have chosen to focus on two examples where the material real and the fictive real become intertwined in complex ways. These chosen examples are ordinary in their presence on YouTube, and do not stand out as unusual. They have each been viewed several thousand times. Thus, the specific phenomenon examined in this article is a theme park and the broader context is online and offline practices producing childhoods. We start with a general description of the park and an analysis of how the fictive real materialize in the park.

\section{The parks material real and fictive real assemblages}

Although ALW is situated on the outskirts of Vimmerby, near an industrial area (Sparrman, 2011), a sense of 'being in nature' or in the countryside is built into the park. An abundance of trees is growing, and in some spots it feels as if you are in a 'real' forest. Since Lindgren's fiction presents stories from the early 1900s, when most of the population lived outside cities, the illustrations in the novels use traditional culture as a resource, and the events at ALW often replicate the book illustrations, and the environments are mainly, but not exclusively, rural.

Figures One and Two exemplify the sense of 'real' nature created in the park; the houses are situated on the outskirts of a forest where foliage encroaches on the 'events'; the milieus built to embody the rural fictive worlds of Lindgren's novels. Nature is, however, tamed and cultivated; this is emphasized by fences, the bridges that allow humans to cross supposedly 'natural' waterways, and the roads that make the landscape accessible while simultaneously restricting people's passage to the outlined trails. At ALW, cultivated 'nature' is beautiful, nostalgic, innocent, clean, safe, pristine and under control; pollution, climate change or a threatening wilderness are absent (Andersson, 2009; Taylor, 2011). The specific cultivated 
natures endow the fictive with normality, making the material real and fictive real mingle into realunreality.

[Insert Figure One about here]

[Insert Figure Two about here]

As demonstrated in Figures One and Two, cultivated nature from the world outside ALW is re-enacted in the park, contributing to the enactment of ALW as simulacrum of a real world (cf. Eco, 1998). What is not obvious from the pictures, however, is that the buildings are constructed on a smaller scale than 'real' houses - almost like miniatures - signalling to visitors that they are true visual copies but not full copies of real houses (see also Sparrman, 2011). The smaller scale also indicates that the houses are created for the primary visitors, the children, rather than the adults, a materialization that stresses the difference between adulthood and childhood. The material reminds visiting children and adults about the notion of children as other and fundamentally different from an adult norm. Difference is, in this milieu of clean, safe and innocent nature, enacted as unique and positive, and not as inferiority or lack of equal resources (cf. Näsman, 1994). We will give more examples of how the park reinforces notions of innocence, and its implications later in the paper. For now, we continue with our exploration of how the material real and fictive real assemblages unfold in the park.

As can be seen in Figure Two, there is an information sign just at the fence corner, creating interference between the material real and the fictive, disturbing the 'realistic' mimicry of the milieu, as information signs are not found in real gardens. The sign encodes the place as cultural heritage, it serves as a reminder that the visitor is visiting a replica of times past displaying memories of what once was (Sparrman, 2011; Schlehe et al., 2010; Watson and 
Waterton, 2010). Moreover, the topic Troublemaker Street creates an assemblage where not only cultural heritage is present, but also the fictive. In this material fictive assemblage cultural heritage is paralleled with fictive notions of how things might have been. Conversely, the text on the information sign also encodes the place as real, implying that this is the real place where a human person named Lotta lives: 'Lotta wakes up one morning and is frightfully angry'. The text on the information sign thus describes a fictional character as though she were a real person, presenting her by first name and assigning agency - implying a human agentive status. Lotta is, however, also a five-year-old fictional girl in the novel Lotta on Troublemaker Street (Lindgren, 1961). The story describes her as an agentive child in a setting epitomizing notions of a romantic childhood where childhood is separated from adulthood (Higonnet, 1998; Holland, 2004; Smith, 2012). Even though it is about a fictional character, the information sign enacts a sense of reality: this is a real place where real children, who have real feelings, live their real childhoods. The information sign is thus simultaneously disturbing the sense of reality and underlining the reality of fiction, making the fictive real (cf. Eco, 1998). As shown so far, fiction is materialized in the parks hybrid and complex environments where contemporary real visiting children and childhoods mingle with the fictive children and childhoods in the material real and fictive real assemblages enacted in the park. More can be said about how inter- and intrapersonal relations are enacted in these hybrid milieus.

\section{Enacting childhood thorough realunreality}

When the park opens its doors to visitors it becomes populated with both ordinary people (i.e. visitors) and actors impersonating the fictional characters in Astrid Lindgren's novels. During the summer, more than sixty well-known humanized fictive characters are found in the park, mingling with the visitors or performing on one of the two stages. Thus, dramatic actors enact fictiveness side by side with 'real' ordinary humans - adults and children. The visual 
documentation, together with numerous blogs on the Internet posted after a visit to the park, display how the visitors represent the real and take part in the enactment by walking around, exploring the events, observing, talking to, or in other ways engaging with, the environment and the actors (Lindgren, 2013). Visitors blend with 'the whole imitative machine' (Eco, 1998: 43) set up to make fiction and the real mix. The 'real' humans and the dramatic actors are, however, also entangled in multiple inter- and intrapersonal ways, as will now be explored more closely.

Films uploaded to YouTube by parents after visits to ALW show how relationships between the material real and the fictive real are enacted in the park. We will give two examples. The first example, in Figure Three, uploaded by a parent, shows how a young actor performs as the well-known fictional character Emil from Lindgren's novels Emil of Lönneberga (Lindgren, 1963; 1966), and film adaptations (Hellbom, 1971, 1972; 1972). Emil is an eightyear-old boy who, because of his curiosity and urge to take his own actions, runs into problems evoking his father's anger.

In the YouTube film, the Emil actor interacts with two visiting children and a female adult at the ALW park (YouTube, retrieved May 24, 2012). The young boy is talking with 'Emil', an older boy acting as the famous fictional character. In this practice, the 'real' boy and girl meet with the material real and fictive real character and vice versa. This moment was singled out by the parents for publication on the Internet and, when we retrieved it, it had attracted more than 151000 viewers. This indicates that the meeting between the real and fictive was something the parents wanted to share with others, and simultaneously, others were eager to share with the parents. In this situation, blurring the boundaries between real and unreal was not regarded as a threat (see introduction), but rather as a resource and inspiration for parents to share with others in an online community. This represents a different way of doing the 
material real and fictional real than the normative stance, which states that a blurring of real and fiction is a marker of abnormality or cause for panic or anxiety.

[Insert Figure Three about here]

We argue that what makes the event taking place in Figure Three special has to do with how the real boy and girl meet with a supposedly unreal Emil who is now appearing in the flesh. The boy touches Emil's body and the girl touches his famous cap; while the boy is talking to Emil the girl is observing him, and scrutinizing him with her gaze. The girl carefully touches Emil's cap, as if checking that this is for real. She does not touch his skin, as the small boy does; instead she connects with Emil by touching the material extension (Emil's famous cap) of the materialized fiction. The boy and girl thus enact the real and fictive real in different ways; by verbal communication, gazes and physical touch. What makes the situation extraordinary is that the fictional character of Emil has come to life, making sensory experiences between real and fictive real possible, and thereby transgressing the distinction usually upheld between the fictional in books and on screen with first-hand sensory experiences.

Being able to enact bodily connections between the real and fictive unreal, we argue, blurs understandings of what a thing 'is' - in an ontological sense. In the actual meeting, the material real and the fictive real become blurred and interrelated not as fiction or fantasy imaginaries but in real practice. The attraction, we argue, lies in the way in which the fictive, unreal childhood enacted by the real fictive character mingles with the real childhoods enacted by the boy and girl - the reality of the event itself. Fiction and real coexist and mingle, not in people's heads, but instead in a real place where others can take part in the enactment and share the experience (cf. Lindgren, 2006) - offline and online, in play and outside play, in private and in public - making the unreal real; creating realunreality. This 
means that fiction, fantasy and the everyday real become inseparable and that ideas about children's inability to separate the real from the unreal (see introduction) indicate children with identity disorders no longer apply. In the context of ALW, there seem to be no such fears. Instead, the interrelatedness between material real and fictive real is supported by the adult community. We want to highlight the active role played by parents in making the enactment of material real and fictive real come together both online and offline; being in the film; as producer of the film and as uploader of the film.

The second example, Figure Four, shows a visiting girl dressed up as the fictional character Pippi Longstocking, famous from several of Lindgren's novels (for example Lindgren, 1945; 1946), film adaptations (Gunvall, 1949; Hellbom, 1973; Riley 1998), television series (Annakin, 1988; Hellbom 1973; Riley, 1998) and computer games (PC \& Macintosh 1997; PC 2002). The film was uploaded to YouTube by a parent (retrieved May 24, 2012). The girl, performing Pippi Longstocking in a similar way to the actors present in the park, wears replicas of Pippi's characteristic clothing, and a wig highlighting the Pippi hairstyle and red hair colour. The hairstyle and colour of the hair signal assertiveness and that Pippi is a special child (Lundqvist 1979). Except for the contemporary trainers, the girl is covered with visual markers identifying her as part of the fiction and/or the actors present in the park. Material objects are thus used to lend authority to the girl to play out being a fictional character, personifying it through her own body and performance. The girl's own 'real' appearance is remade to create a similarity with a fictional character, supporting an identity where 'real' self and fictive real become interrelated. We will explore this in more detail.

The film begins as the girl is mounting a play horse, serving as a replica of Pippi Longstocking's horse, Lilla Gubben, a white horse with black spots that lives together with Pippi and her monkey in her home, Villekulla Cottage (Pippi's mother is dead and her father 
lives on an island in the Pacific Ocean). The replica of the horse, together with the clothing and the wig, are, as already mentioned, materializations of the fictive real.

[Insert Figure Four about here]

The girl pretends to ride the horse and says: 'I'm arriving at Villekulla Cottage'. She dismounts from the horse and enters the model house, Villekulla Cottage: a materialization of fiction making it possible to engage with it. The girl is, we claim, using materiality in complex ways to gain authenticity from the fictive to actually be a fictive character herself. Her actions are different from the experience of reading or listening to a novel: She is naming a fictional place, positioning herself in it, and acting like the fictional character she 'is'. The uploading parent's comment on the film is: 'The cutest Pippi in the world', thereby confirming that the girl is Pippi and even better than the original as she is cuter than the real fictional one.

What is of particular interest here is the way in which it is not only the park that encourages this mingling of real and unreal on several different levels at the same time but also that the adult filming the girl's activity engages in, and encourages, the interaction between the real and fictive real. This means that the realunreality does not solely belong to children's play but, in addition, to adults' ideas about what childhood as well as adulthood should be. Children should live in and with fiction and adults should support this process. Adults, thus, encourage children to interact with the materialized fiction, and give their support by documenting it (Economou and Hergli, 2010; Lindgren, 2013), standing by as observers and by doing so marking their adult positions (Lindgren, 2012; Sparrman and Lindgren, 2010) and forming practices where realunreality enact childhood in new ways.

When the parents upload films from their visit onto YouTube they are also publishing their own versions of these children's cultural products, which are legendary in Sweden today; 
these parents are publishing their own versions of the film Emil and the film about Pippi Longstocking, with their own children participating in different ways. This form of demotic presence stands out as innovative in the mingling of material real and fictive real, as well as the way in which it positions their children in the media. What these kinds of films have in common is an enactment of realunreality with the parents' own children as the main characters. The real material and fictive real assemblages enacted in the park thus creates new childhood practices and ways to 'do' contemporary childhoods.

We will now turn to the more unusual - in the ALW context - urban environment to discuss how the fictive urban realities enact childhoods and childhood innocence.

\section{Assemblages of realunreality and contemporary childhoods}

The model town and event Tiny Town differs from the other events in the park in that it is not a rural setting, as is most common in ALW. The Tiny Town setting consists of several houses in traditional style with gardens, street scenes, a city hall, hotel and town square - to mention but some of the attractions. In some of the houses there are passages so that children can enter and cross through to another street, and there are also sound effects on one of the streets, where you hear real children's voices telling stories, singing and giggling, thus prompting a sense of reality in this 'toy city' (Eco 1998: 41) within a 'toy city' - the park itself. The sense of being in a fantasy world is enhanced by the fact that a visitor cannot enter the shops but only look in through the windows. In this section we will explore how the material real and fictive real intertwine with past and present enacted as part of the same time and space; a pastpresent (King, 2012). Past and present continually converge, collapse and co-invent each other, where the node holding them together is fiction and childhood.

It is a romanticized image of history (Giroux, 1997: 56) that is staged in Tiny Town: a history where the streets were clean and organized, children played and went to school and adults 
worked. Candy and toys were what children dreamt of. It was a world without inequalities or hardship. The information sign describing Tiny Town emphasizes the realistic dimension, that it is a duplicate of the town of Vimmerby near which the ALW park is situated. In addition to presenting this model world as cultural heritage, a replica of a real town from the early nineteen hundreds, the information sign simultaneously makes connections with Lindgren's fiction: 'The small shops and streets, the hotel garden and the marketplace are all to be found in different books.' The reasoning is that the real model world can be traced to fiction; one can discover these 'real'-life duplicates in the fiction. A link is construed between historical time as reality and as an inspiration for fiction and then back to real life as enacted in the model worlds (which constitute lived experiences for the visitors). The information sign is thus an agent in the mingling of history, fiction and lived worlds.

In Tiny Town, a sign on a traditional Swedish-style house signals the presence of an exhibition on Astrid Lindgren's SOS Children's Village, Bouar, in the Central African Republic. The exhibition is located inside the building (one of the few buildings that can be entered) and consists of texts and photographs covering the walls. Information in English tells us that the Central African Republic is 'one of the poorest countries in the world' where '280,000 children have lost one or both of their parents'.

[Insert Figure Five about here]

The presentation tells us that the initiative to support and build the village was part of the centenary celebration of Astrid Lindgren's birth and Figure Five displays how a 'model shows the new village'. What is happening here is that a model world built to support and save children and their families is presented in the context of a model of a fictive world alleged to present a traditional Swedish village in historical time. The intermediary links between these 'worlds' are Astrid Lindgren and notions of childhood in fiction and in contemporary society. 
In addition, in order to show what the legacy of Astrid Lindgren has produced and contributes to, the exhibition seeks to evoke interest in funding a second new Astrid Lindgren's Children's Village in the Central African Republic.

The second part of the exhibition aims to raise funds for a new project. It presents the ways in which contemporary children and childhoods are created and affected by Swedish efforts in the name of the children's novelist Astrid Lindgren. The links between 'here' and 'there' are explicit: ‘Help us to build Astrid Lindgren's second child village. Noisy Village in Bossangoa'. As the quotation shows, the imagined new village in the Central African Republic is named after one of the events in the Astrid Lindgren's World fictionalizing the novel with the same name: Noisy Village [Sw. Bullerbyn]. In doing this, the builders are establishing complex connections between fictive imagined worlds based on Lindgren's authorship with its specific notions of childhood, and an imagined new real village for real living children in another part of the world in contemporary time. A reference to Pippi Longstocking's renowned 'treasure chest' [Sw. skattkista] establishes these connections: 'If you want to help us, please leave a coin in the treasure chest.'

Links are also established between the children who have received help from the first Astrid Lindgren Children's Village and those who will live in the second, planned one. Images of good outcomes and continuing needs are presented side by side: for example, statements that 'Children are safe in their new families' are paralleled by a presentation of the facts that other children are abandoned and need education, new homes and new families. A childhood occupied by work is held out as a negative reality that these children need - and they themselves want - to escape: '49 percent of children between 10 and 14 years of age are working'. This statement is reinforced by a boy seated in the lower right-hand corner of a photograph covering the wall (Figure Six), speaking in his own voice while looking directly into the eyes of the ALW visitor: 'It's more fun to be in school than to work in the 
marketplace.' A distinction is implicitly made between these children in need and those having access to ALW.

\section{[Insert Figure Six about here]}

At ALW, play - not work - is the key activity for children visiting Lindgren's fictive worlds. It is about 'being able to play when you want to, having nature and the sea always nearby, and about how happy these simple things can make you feel' (Park Guide, 2011: 18). The African villages built in Lindgren's name similarly seek to give children a 'happy childhood', and one that is safe and secure: 'here they can stay until they are grown up.' An implication is that the children - at ALW or in the Central African Republic - are being protected by adults, and by Astrid Lindgren's world and legacy. The experience enacted for both children and adults is a traditional western childhood, where children are dependent on adults who know and translate what children's best interest are: Children should want to play and not work (cf. Cannella and Viruru, 2004). The notion of childhood enacted here is in accordance with dominant western discourses of childhood, in which children are presented as inherently innocent, protected and not taking part in productive work (Cannella and Viruru, 2004). At ALW, historical and contemporary childhoods, 'our' and 'the others'" childhoods, national and foreign childhoods, are simultaneously enacted in a material real and fictive real setting. A shared feature of all these sets of concepts, related by and, is innocence. The material real and fictive real together produce multifaceted layers of innocence; the innocence of childhood is intertwined with historical innocence (of childhood) and nostalgia.

To conclude, Tiny Town is a complex environment where traditional Swedish nostalgic and sentimental notions of how a good social/natural milieu serves to create good childhoods meet - in historical and contemporary, material real and fictive real time - contemporary notions of how children in need in foreign countries ought to be helped. The poor foreign children can be 
protected and saved in the same way that Swedish children in historical time were protected and saved while living out their good childhoods, childhoods now re-enacted in the park. Fiction is the source of a Swedish model world, while a fiction writer inspires the creation of material real worlds (presented as models in Tiny Town) in contemporary foreign countries. Fictive worlds created as part of children's childhoods generate an interplay and interconnectedness between time and space and between what is material real and fictive real, past and present, close and far away. These fictive materializations construe new alignments between historical and contemporary notions of children's needs: Children need protection in order to be or become innocent children; to experience a 'romantic childhood', the most valued childhood in western societies, where children are innocent, playing and learning (Cannella and Viruru, 2004; Higonnet, 1998; Holland, 2004; Taylor, 2011). These enactments include a re-enactment of the colonization of the non-western (Cannella and Viruru, 2004), enacted through a mingling of the material real and fictive real. At ALW, realunreality created in materialfictive assemblages becomes part of the western post-colonization of the South.

\section{Conclusion: Realunreality, materialized fiction and materialized childhoods}

In this paper we have discussed how childhood practices enacted at a Swedish theme park based upon the work of novelist Astrid Lindgren produce new combinations of the material real and fictive real. Astrid Lindgren's World (ALW), in Vimmerby, Sweden, is a place where fiction and childhood are enacted in multiple interpersonal and personal-material relationships when real childhoods (visiting children) and fictive real childhoods (childhoods in fiction) meet and co-exist. Materialities invested with real and fictional childhood innocence - happiness, playing, being close to nature and nostalgia - mingle with lived childhood innocence and generate a setting in which the fictive stimulates real activity and vice versa; the real stimulates the fictional. ALW enacts the material real and fictive real as 
interconnected, making what we refer to as realunreality part of contemporary (western) childhoods.

At ALW, we argue, the fictive is enacted in real terms, exhibiting complex interrelations and interconnectedness with cultural history, contemporary times, and the national and foreign. The enacted materialized fiction at ALW is achieved through an abundance of fictiveness that mingles the material real and the fictive real. ALW is not fiction and it is not philosophy: ALW is a real place where fantasies and cultural understandings are enacted. If ALW has an 'origin narrative' (Haraway, 1989: 370), it is about enacting fictive materializations entangled with childhoods where material real and fictive real become intertwined.

Enacting childhoods and fiction reinforces traditional notions of innocence and nostalgia. In doing so, traditional power relations are re-enacted that position adults as in control and with power, and children as the controlled and the ones given power when adults want to do so, in Sweden and in foreign countries. Adults are the providers of children's worlds and perspectives (Cannella and Viruru, 2004; Smith, 2012). Such a notion does not fit well with the contemporary call for new perspectives on children and adults as both complete and incomplete, with the aim of blurring the distinctions between adulthood and childhood and making both more equal (Cannella and Viruru, 2004; Gallacher and Gallagher, 2008; Halldén, 2007; Smith, 2012). Instead, the new forms of realunreality that children and adults enact together become an obstacle for child empowerment. Innocence, nostalgia and euphoria, fuelled by 'safe' fiction, create a condition where the socially enforced aim is not change, but conservation.

To conclude, in parallel with the hybridity and interconnectedness in terms of how the material real and the fictive real are enacted in the park, traditional categories of separation between adults and children are reproduced. This is not done as a result of anxiety about 
mingling reality and the fiction, as often suggested in other studies (see introduction). On the contrary, adults are supporting and co-creating the material real and the fictive real where children play out childishness and adults play out slightly new versions of adulthood, as documenters providing and staging safe and secure childhoods. What the emphasis on innocence does is to re-inscribe adults as inherently powerful. At ALW this is mainly achieved through multiple investments in childhood (and nature) innocence, nostalgia and romanticized history.

\section{References}

Aarsand P (2007) Around the Screen: Computer Activities in Children's Everyday Lives (Diss.). (Linköping Studies in Arts and Science, 388) Linköping: Linköping University.

Althén K (2010) Att våga tänka annorlunda [Dare to think differently]. In: Leif Jonsson (ed) Astrid Lindgrens världar $i$ Vimmerby: En studie om kulturarv och samhällsutveckling [Astrid Lindgren's worlds in Vimmerby: A study about cultural heritage and societal development]. Lund: Nordic Academic Press: pp. 64-104.

Andersson, P. 2009. Naturligt=bra? Funderingar over ett värdeladdat begrepp

[Natural=good? Reflections on a value loaded concept]. In: Halldén G (ed) Naturen som symbol för den goda barndomen [Nature as symbol for a good childhood]. Stockholm: Carlssons: pp. 25-33.

Annakin K (1988) Pippi är starkast $i$ världen [New Adventures of Pippi Longstocking ] [Motion picture]. Columbia Pictures.

Braidotti R (2013) The Posthuman. Cambridge, UK \& Malden, USA: Polity Press.

Cannella GS, and Viruru R (2004) Childhood and Postcolonization: Power, Education and Contemporary Practice. New York \& London: Routledge.

Cardell D (2013) Tysta barn och talande robotar. Om tema- och nöjesparksforskningens problem och barnstudiernas möjligheter [Silent children and talking robots: On themepark- and amusementpark research and child studies opportunities]. In: $N u$ vill jag prata! Barns röster i barnkulturen [Now I want to speak! Children's voices in children's culture]. Stockholm: Stockholms universitets förlag, pp. $141-152$.

Danielsson J, Hallgren E, Lindgren M, Lazaro MC, Pernemalm P, and Young S (2011) Upplevelser $i$ världsklass: En rapport för Parks and Resorts Scandinavia [World-class Events: A Report for Parks and Resorts Scandinavia]. Stockholm: Kairos Future.

Eco U (1998) Faith in Fakes: Travels in Hyperreality. London: Minerva.

Economou, Konstantin och Hergli, Rakel (2010) Samtidigt i Vimmerby, I: Leif Johansson (red) Astrid Lindgrens världar i Vimmerby: en studie om kulturarv och samhällsutveckling. Lund: Nordic Academic Press.

Fairclough N (2005) Analysing Discourse: Textual Analysis for Social Research. London and New York: Routledge. 
Gallacher L-A, \& Gallagher M (2008) Methodological immaturity in childhood research? Thinking through 'participatory methods'. Childhood 15(4): 499-516.

Gillis JR, Gutman M, and De Coninck-Smith N (2008) The Islanding of children-Reshaping the mythical landscape of childhood, In: Gutman $\mathrm{M}$ and de Coninck-Smith N (eds) Designing Modern Childhoods: History, Space, and the Material Culture of Childhood. New Brunswick, NJ: Rutgers University Press.

Giroux HA (1997) Are Disney movies good for kids?, In: Steinberg SR and Kincheloe JL (eds) Kinderculture: The Corporate Construction of Childhood. Boulder and Oxford: Westview Press pp. 53-67.

Gunvall P (1949) Pippi Långstrump [Pippi Longstocking] [Motion picture]. AB SandrewProduktion.

Halldén G 2007 (ed.) Den moderna barndomen och barns vardagsliv [Modern Childhood and Children's Everyday Lives]. Stockholm: Carlssons.

Haraway D (1989) Primate Visions: Gender, Race and Nature in the World of Modern Science. New York \& London: Routledge.

Helander K (2011) 'Den var rolig och så lärde man sig nånting, men jag kommer inte på vilket det var'. Om barnteater och receptionsforskning. ['It was fun and you learned something, but I cannot remember what': About children's theater and reception research] Locus 3-4/11: 81-97.

Hellbom O (1973) Pippi Långstrump [Pippi Longstocking]. [Motion picture and TV-series]. Sveriges Radio AB.

Higonnet A (1998) Pictures of Innocence: The History and Crisis of Ideal Childhood. London: Thames and Hudson.

Holland P (2004) Picturing Childhood: The Myth of the Child in Popular Imagery. London, New York: I.B. Tauris.

King K (2012) Pastpresents: Playing cat's cradle with Donna Haraway. Essay in Thinking with Donna Haraway. Webfestscrift for Donna Haraway online at:

http://playingcatscradle.blogspot.com/, retrieved May 25, 2012.

Law J (2004) Enacting Naturecultures: A Note from STS, published by the Centre for Science Studies, Lancaster University, Lancaster LA1 4YN, UK, at http:/www.comp.lancs.ac.uk/sociology/papers/law-wnacting-naturecultures.pdf. Published $26^{\text {th }}$ February 2004.

Law J and Urry J (2003) Enacting the social. Published by the Department of Sociology and the Centre for Science Studies, Lancaster University, Lancaster LA 14 YN, UK. Retrieved 1 November 2010 from http://www.comp.lancs.ac.uk/sociology/papers/Law-Urry-enacting-the Social.pdf.

Lindgren A (1961) Lotta på Bråkmakargatan [Lotta in Troublemaker Street]. Stockholm: Rabén \& Sjögren.

Lindgren A (1963) Emil i Lönneberga [Emil of Lönneberga]. Stockholm: Rabén \& Sjögren. Lindgren A (1966) Nya hyss av Emil i Lönneberga [New pranks by Emil of Lönneberga]. Stockholm: Rabén \& Sjögren.

Lindgren A (1945) Pippi Långstrump [Pippi Långstocking]. Stockholm: Rabén \& Sjögren. Lindgren A (1946) Pippi går ombord [Pippi goes on board]. Stockholm: Rabén \& Sjögren. Lindgren A-L (2006) Från små människor till lärande individer. Föreställningar om barn och barndom i förskoleprogram 1970-2000. [From Little People to Learning Individuals: Notions of Children and Childhood in Preschool Programs 19702000] Lund: Arkiv Förlag (Stiftelsen Etermedierna i Sverige 16). 
Lindgren A-L (2012) Ethical issues in pedagogical documentation: Representations of children through digital technology. International Journal of Early Childhood 44(3): 327-340.

Lindgren A-L (2013) Barnkultur och natur i Astrid Lindgrens Värld. Gamla och nya barndomsideal [Child Culture and Nature in Astrid Lindgren's World. Old and New Notions of Childhood]. In: Helander K (ed) Nu vill jag prata! Barns röster i barnkulturen. [Now I want to talk! Children's voices in children's culture] Stockholm: Stockholms Universitet, 99-115.

Lukas, SA (2008) Theme Park. London: Reaktion Books.

Lundqvist U (1979) Århundradets barn. Fenomenet Pippi Långstrump och dess förutsättningar [The Children of the Century: The Phenomenon Pippi Longstocking and its Basis]. (Diss.). Stockholm: Rabén \& Sjögren.

Mitrašinović M (2006) Total Landscape, Theme Parks, Public Space. Aldershot: Ashgate. Näsman E (1994) Individualization and institutionalization of childhood in today's Europe.

In: Qvortrup J, Bardy M, Sgritta G and Wintersberger H (eds) Childhood Matters: Social Theory, Practice and Politics. Brookfield VT: Avebury, pp. $165-187$.

Park Guide (2011) Print: Strokirk-Landström. Text page 4, 6-17, 19 @ Margareta Strömstedt. DTRT.

PC \& Macintosh (1997) Pippi [Computer game].

PC (2002) Här kommer Pippi Långstrump [Here comes Pippi Longstocking]. [Computer game].

Pettersson Å (2013) TV for Children: How Swedish Public Service Television Imagines a Child Audience. (Diss.) Linköping: Linköping University.

Riley P (1998) Pippi Longstocking [Motion picture and TV-series]. Canada/Germany: Nelvana, Svensk Filmindustri (SF), TFC Trickompany Filmproduktion.

Schlehe J, Uike-Bornmann M, Oesterle C and Hochbruck W eds (2010) Staging the Past. The Environments in Transcultural Perspectives. History in Popular Cultures, Vol 2, Bielefeld: Transcript Verlag.

Smith K (2012) Producing governable subjects: Images of childhood old and new. Childhood 19(1): 24-37.

Sparrman A (2002) Visuell kultur i barns vardagsliv - bilder, medier och praktiker (Diss.).

[Visual Culture in the Everyday Life of Children - Pictures, Media and

Practices] (Linköping Studies in Arts and Science, 250). Linköping: Linköping University.

Sparrman A (2011) Barnkulturens sociala estetik [Social aesthetic in children's culture] Locus 23(3-4): 25-44.

Sparrman A and Lindgren A-L (2010) Visual documentation as a normalizing practice: A new discourse of visibility in preschool. Surveillance \& Society 7(3-4): 248-261.

Strömberg P (2003) Designade dagdrömmar [Designed daydreams]. Valör, 1.

Taylor A (2011) Reconceptualizing the 'nature' of childhood. Childhood 18(4): 420-433.

VR 2009-2384 (2009) Culture for and by children: A visual ethnographic study of children's museums, theme parks, amusement parks and science centers. Application to the Swedish Research Council (VR).

Watson S and Waterton E (2010) Introduction: A visual heritage. In: Waterton E and Watson $\mathrm{S}$ (eds) Culture, Heritage and Representation: Perspectives on Visuality and the Past. Farnham Surrey: Ashgate, pp. 1-18.

Woolgar S (ed.) (2002) Virtual Society? Technology, Cyberbole, Reality. Oxford, New York: Oxford University Press. 
Figures and Captions (1-6)

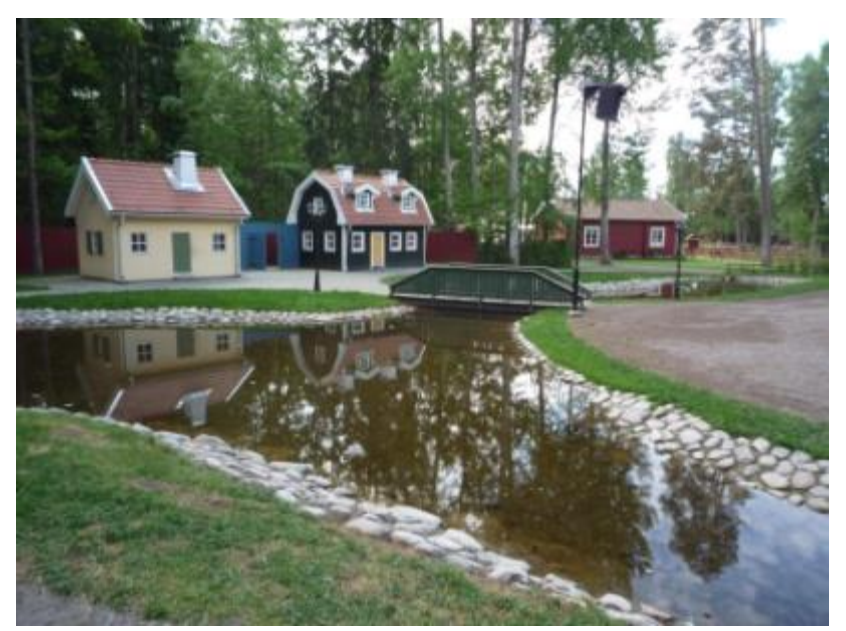

Figure 1: Junedale. Lindgren's nostalgic and pristine countryside. Visual documentation 2010.

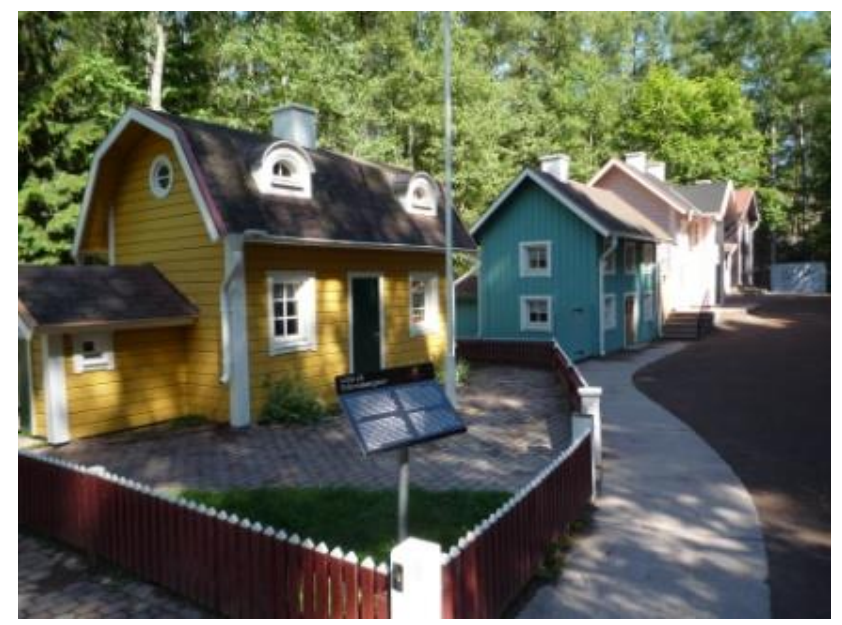

Figure 2: Troublemaker Street. Houses on the outskirt of a forest, with fences and signs.

Visual documentation 2010. 


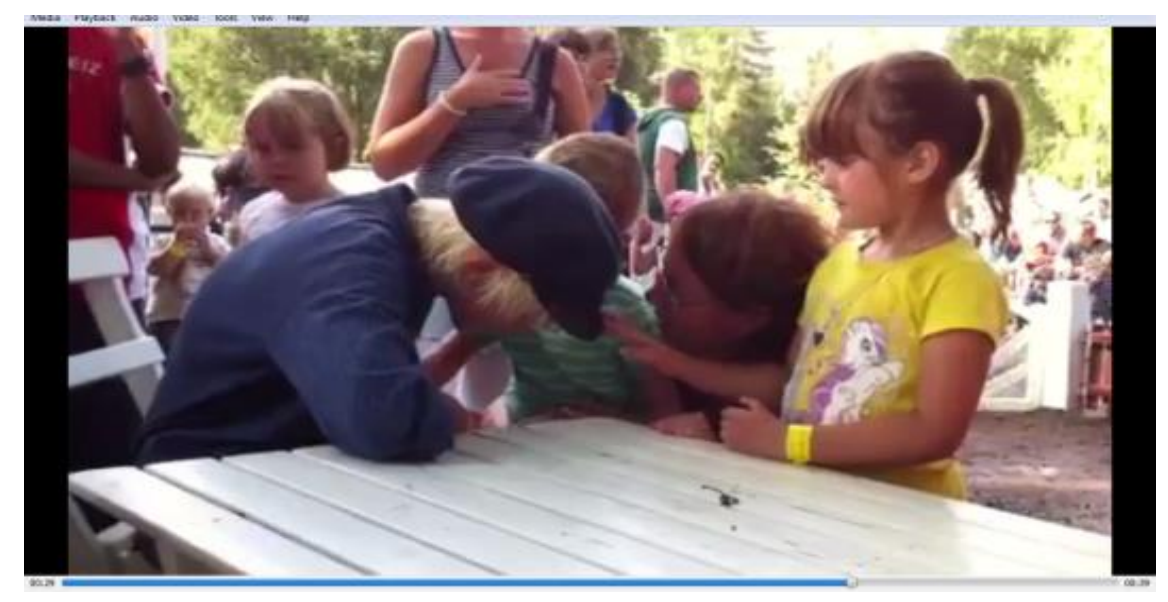

Figure 3. Emil of Lönneberga meeting visitors at Astrid Lindgren's World. YouTube, retrieved May 24, 2012.

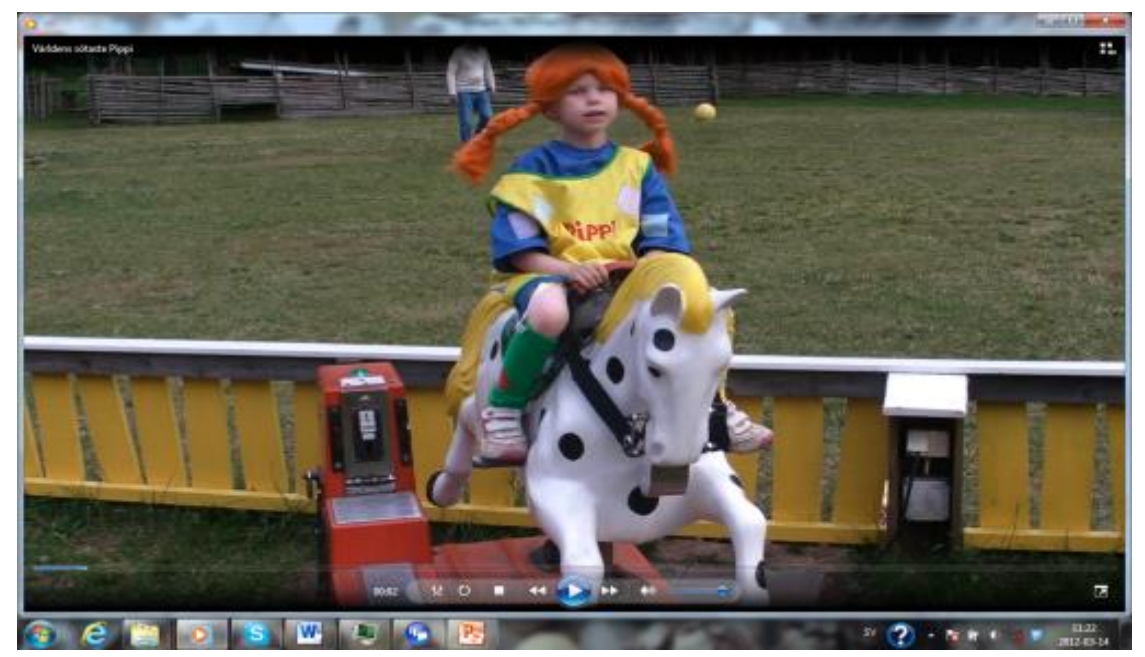

Figure 4. Girl dressed up as Pippi Longstocking. YouTube, retrieved May 24, 2012. 


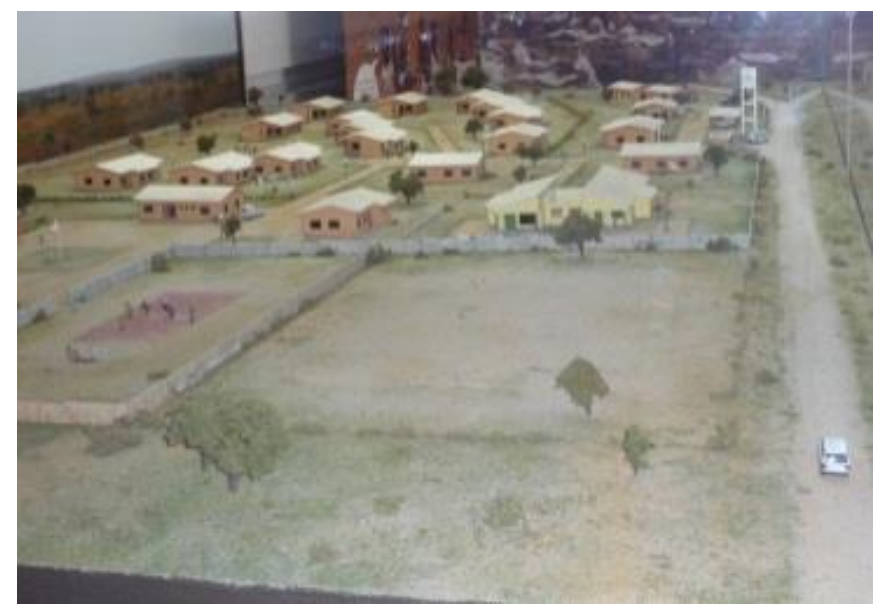

Figure 5. Model of the Astrid Lindgren's Children's Village in Bouar in the Central African Republic. Visual documentation, 2010.

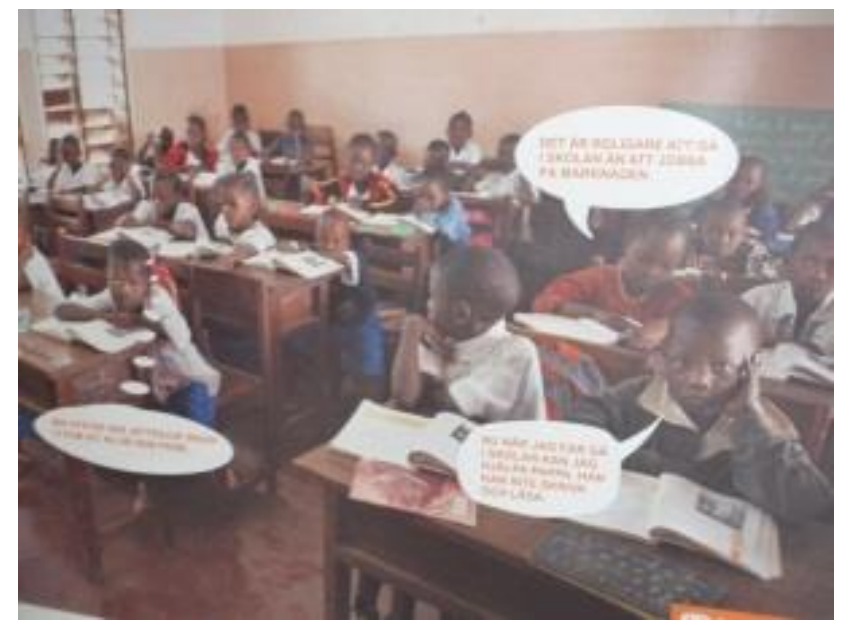

Figure 6. Exhibition about the Astrid Lindgren SOS Children's village in Bouar, Central African Republic. Visual documentation, 2010. 